\title{
Theory and practice of European co- operative education and training for the support of energy transition
}

Stephan Maier ${ }^{1 *} \mathbb{D}$, Michael Narodoslawsky ${ }^{1}$, Lidia Borell-Damián², Maarten Arentsen ${ }^{3}$, Marlene Kienberger ${ }^{1}$, Wolfgang Bauer ${ }^{1}$, Maria Ortner ${ }^{4}$, Nigel Foxhall ${ }^{5}$, Gerhard Oswald ${ }^{6}$, Joan-Marc Joval ${ }^{7}$, Yoram Krozer ${ }^{3}$, Theresa Urbanz ${ }^{8}$, Christian Sakulin ${ }^{8}$, Sebestyen Tihamer-Tibor ${ }^{9}$ and Viktorija Dobravec ${ }^{10}$

\begin{abstract}
Background: European visions such as the European Commission's Strategic Energy Technology (SET) Plan and the SET Plan Roadmap Education and Training encourages higher education institutions (HEI) and business to establish adequate co-operative education and training approaches in the face of the challenges posed by the energy transition necessary to achieve European Union's climate goals. The development of integrated co-operative education, training and learning systems is a fundamental strategy to foster co-operation between academic institutions and business.
\end{abstract}

Methods: Available sources about the theoretical and practical knowledge of co-operative education and training are limited. To identify available information and create new information where there is no this research was carried out by means of a literature study and a database search on existing co-operative education formats. This was supplemented by an analysis of seven actual case study reports regarding examples drawn from the BioEnergyTrain (BET) project commissioned under the European Union's Horizon 2020 programme.

Results: Co-operation for educational purposes between higher education institutions (HEI) and business exists on the curricular, course and internship level.Considering the total number of studies on a curricular level in Europe, only very few co-operative education programmes exist. On the curricular level, most of the appropriate formats are dual studies with Bachelors' programmes, fewer are dual studies with Master's programmes.

Co-operation formats on the course level do not follow institutionalised rules and are case-specifically applied. The studies presented in this journal dealing with practical examples emphasise the high potential for improving student's skills and insight into business that such co-operative formats offer to universities and business partners.Co-operation on an internship level has a long tradition of exposing students to the business environment they will later work in. Internships however do not provide high-intensity co-operation between business and HEls. Therefore, it is outside the focus of this paper's attention.

Results of statistical analysis reveal a total number of 19,822 related dual study programmes in the year 2018 alone in Germany whereas, for co-operative curricula on a master's level, just 73 can be tracked in whole Europe. Results of the case study reports are further discussed in Additional files 1, 2, 3, 4, 5, 6, 7 and 8.

(Continued on next page)

\footnotetext{
* Correspondence: stephan.maier@tugraz.at

'eseia/Graz University of Technology, Graz, Austria

Full list of author information is available at the end of the article
}

(c) The Author(s). 2019 Open Access This article is distributed under the terms of the Creative Commons Attribution 4.0 International License (http://creativecommons.org/licenses/by/4.0/), which permits unrestricted use, distribution, and reproduction in any medium, provided you give appropriate credit to the original author(s) and the source, provide a link to the Creative Commons license, and indicate if changes were made. 
(Continued from previous page)

Discussion: Existing research and descriptions of co-operative education and training are limited. However, based on the available sources, this study discusses co-operative education regarding its roots, types, role of business, type of rotation, salary, and legal issues as well as efforts on a European level to create and put into practice adequate forms of co-operative education supplemented by case studies.

The huge gap between generally available dual study programmes on a bachelor's and master's level and available studies throughout Europe is partly related to the fact that most of the dual study programmes are on a bachelor's level and partly related to a limited sharing of collective university information on comprehensive platforms. Through the main foci of the study on the theoretical background of co-operative studies as well as the practical implementation of co-operative education practice, all European academic institutions could not be contacted and analysed individually.

Conclusions: There is not much available data on co-operative study programmes. This may be due to the fact that co-operation in education and training between academic institutions and business plays only a minor role in the overall education system.

Apart from dual study programmes, co-operative education and training formats usually are not defined unambiguously because the number of co-operative education programmes directed towards meeting the challenges posed by the energy transition is low.

Although both the SET Plan Roadmap Education and Training developed within the SET Plan process and the Action Agenda for European Universities developed by the European University Association (EUA) identify co-operation between HEls and business as crucial to meet these challenges (Borrell-Damian and Narodoslawsky [Additional file 1]), much remains to be done in this respect. There is a need for institutions all over Europe which are able and willing to provide a platform for such co-operation and co-ordinate the development of co-operative learning formats, especially on the course level, across sectoral boundaries.

The energy transition definitely requires adequately trained people to deal with and create low emission energy systems and the challenges arising therewith.

Keywords: Co-operative education and training, Dual learning, Energy turn, Energy transition, Energiewende

\section{Background}

The development of integrated co-operative education, training and learning is a fundamental necessity [1] to foster co-operation between academic institutions and business [2], find options to train graduates in response to business needs [3] and collaborate between higher education and business [4]. This is particularly important in fields bound to experience major ecological, technological, economic and social transitions and that at the same time are crucial for human development [5]. One of these fields is the energy sector. Co-operative education and training must be promoted for the good of the energy transition [6] and linked to sustainability [7] and Sustainable Development Goal 4 (quality education) providing support for holistic and transformational Education for Sustainable Development [8].

The European Union has defined very general prevailing conditions for the development of energy technologies and relevant education in Europe [9] which is supplemented by the more detailed Strategic Energy Technology (SET) plan [10] as part of which the Roadmap on Education and Training [11] has been determined.

\section{EU 2020 strategy}

From the perspective of European policy, the 'Europe 2020 strategy' emphasises smart, sustainable and inclusive growth. The European Commission defined 5 targets for a top-down stimulation for the fulfilment of basic requirements [9]:

- Employment - 75\% of people aged 20-64 to be in work

- Research and development (R\&D) - $3 \%$ of the EU's GDP to be invested in R\&D

- Climate change and energy

- Greenhouse gas emissions 20\% lower than 1990 levels

- $20 \%$ of energy coming from renewables

- 20\% increase in energy efficiency

- Education

- Rates of early school leavers below $10 \%$

- At least 40\% of people aged 30-34 having completed higher education

- Poverty and social exclusion

- At least 20 million fewer people in-or at risk of-poverty/social exclusion

This strategy includes measures to halt climate change. Because education is not regulated on the EU level, national education and training approaches need to be comprehensively linked to energy transition which is necessary to meet the Union's climate goals. The targets 
related to climate change come within reach most unevenly across the EU's 28 member states [12].

In 2002, the Council of the European Union has started the EU cooperation in education and training (ET 2020) in order to provide the strategic framework for co-operation in education and training up to 2020; ET 2020 is defined as a fundamental pillar to meet '... the many socio-economic, demographic, environmental and technological challenges facing Europe and its citizens today and in the years ahead...' [13].

\section{Strategic Energy Technology (SET-Plan) and Roadmap Education and Training}

Facing the challenge of developing a low-carbon, secure and affordable energy technology system, the European Union (EU) promotes a fundamental energy transition. For this purpose, it devised the SET-Plan which promotes an increased use of renewables ('...accelerate the development and deployment of low-carbon technologies...') and the development of an innovative cost-competitive and efficient energy system [14].

In order to create a framework to support the 'Availability and mobilisation of appropriately skilled human resources', the SET Roadmap Education and Training was established [15]. This was a consequence of the recognition that 'one of the key elements in supporting energy technology innovation at EU level is the availability and mobilisation of appropriately skilled human resources' [10]. In the Education \& Training Roadmap, the European Union mentions '...that one of the key elements in supporting energy technology innovation at EU level is the availability and mobilisation of appropriately skilled human resources...' and 'challenges for the education and training institutions and their legal frameworks will be to ensure a workforce flow of researchers, engineers and technicians who are able to generate new knowledge and to meet the requirements of evolving technologies and labour markets. In parallel, training for managers and decision-makers in the field is needed to design and implement appropriate frameworks for the development and deployment of new energy solutions.' [16]

In their analysis of this special issue [Borrell-Damian and Narodoslawsky [Additional file 1], Narodoslawsky and Borell-Damián highlight the need for intensified promotion of collaborative education formats on the basis of the Strategic Energy Technology (SET) Plan Roadmap on Education and Training (SRMET [17]) and the Action Agenda for European Universities (AAEU [18]). The latter document provides a strategy for European universities to cope with the challenges of the energy transition. The analysis mentioned above reveals that the EU and the European universities consider co-operation in and shared responsibility for education of the future workforce as critically important to be able to meet the education and training challenges posed by energy transition.

The authors identify a strong tradition of co-operative education in vocational training in many European countries. However, they miss an equally strong endeavour in the field of educational co-operation between business and universities. They find that neither academia nor business has taken common responsibility for the education of future experts and that both have not deployed the substantial resources necessary for true common educational efforts.

In order to develop adequate co-operation formats, Narodoslawsky and Borell-Damián list the requirements to breach the walls between business and universities. The changes necessary for the energy transition with its varying requirements have to be put into effect in order to train the future workforce in an appropriate educational environment including efficient high-quality training networks. Thus co-operative learning formats can '...become major drivers for innovation in the education of future workforce...' as they fulfil '...the need to educate students in the complexities and interconnected nature of the energy systems in relation to our societies, at local as well as global levels ...'.

The development of a future-oriented European education programme aligned to the challenges posed by the energy transition is an essential part of the EU 2020 plan in order to keep Europe in the role of a technology leader while at the same time contributing to the effort to curb climate change.

On a global scale, the United Nations defined within its set of Sustainable Development Goals sub goal 4-quality education-which asks for education including issues like sustainable development and sustainable lifestyles [19]. The UN misses to directly discuss the development of environmentally clean energy technologies as one important aspect to reach this goal [20]. There is an obvious lack of integration of all 17 Sustainable Development Goals into an educational context.

$\mathrm{UN}$ and EU may set the frame. The effective implementation of educational goals has to be realised on a national and regional level because the ultimate competence lies there. An integrated development of cooperative education and training formats has to be executed by national institutions and businesses. Certainly, co-operation is not only needed across sectors but also across national borders as the challenges of the energy transition are international and so are the challenges of technology development and implementation.

Finally, co-operative education formats need to be adapted to the motivation driving their implementation. 


\section{Motivation for the development of co-operative education formats}

Quality of students' learning increases in a work-studyenvironment with a strong relationship to effective mentors [21]. This also increases a student's understanding of her/his future work environment. Students benefit from workplace supervisors who create an authentic environment confronting them with real-world problems strengthening their self-confidence by exchanging ideas at an eye-level [22]. Thus, academic supervisors add to the student's theoretical knowledge. The implementation of these changes into educational practice forces educational institutions as well as entrepreneurs to intensify their collaborations [23].

Healy et al. measured benefits academic institutions were able to derive from university-business co-operation resulting in co-creation and co-production of knowledge [24]. Possible benefits for students are

- Increased employability

- Acquirement of soft/technological skills and up-todate knowledge

- Better understanding of the business world

- Mutual learning with employees

- Joint courses on modern technologies

- Participation of lecturers with business experience

- Acting in an integrated system as a 'motor of innovation' for society

- Extended social networks

Students, university and business can benefit mutually from a well-co-ordinated co-operative education format. Optimal co-operation results in an exchange of skills between all beneficiaries, enhanced chances for students on the job market, increased research portfolios for universities and better qualified employees as well as in innovation advantages for business, to name only the most important impacts. There is a wide variety of possible formats, ranging from dual study programmes on the curricular level to various co-operative course formats, internships and thesis programmes funded by business. However, design and intensity of the co-operation are dependent on the desired results.

\section{Definition of co-operative education and training}

In general terms, Ricks suggested that co-operative education should foster an integrated educational and work experience, self-directed learning, reflective practice and transformative learning [25].

The quality of co-operation between education institutions and business/industry can differ vastly. A co-operation format can be defined as less satisfactory when it just includes defining topics for Bachelor's or Master's theses and providing internships in industry. Better results can be reached when the co-operative aspect includes lecturers from industry and joint courses for students and industrial employees. Results can further improve when business co-operates in the development of curricula and theoretical learning phases and higher education institutions (HEIs) are intertwined with practical phases in a business or industrial environment and when business and HEIs take joint responsibility for the learning outcome of students. Conventional co-operative education and learning formats are defined in different ways. A common feature of these definitions is an integrated learning approach which links theoretical education with practical work experience as described by the platform Co-operative Education and Work-Integrated Learning Canada [26], or as the World Association for Cooperative Education, an NGO linking higher education institutions, employers and public authorities, defines [27]:

'Cooperative \& Work-Integrated Education (CWIE) includes: cooperative education (all disciplines); clinical rotations; community research; internships (all disciplines); international work (co-op) exchanges; learningintegrated work; undergraduate \& graduate research; service-learning; and practica, and other forms of learning where education is integrated with work experience.'

A US legal document describes the purpose and definition of co-operative education as follows [28]:

\section{(a) Purpose}

It is the purpose of this part to award grants to institutions of higher education or consortia of such institutions to encourage such institutions to develop and make available to their students work experience that will aid such students in future careers and will enable such students to support themselves financially while in school.

(b) Definition

In this part, the term 'cooperative education' means the provision of alternating or parallel periods of academic study and public or private employment to give students work experiences related to their academic or occupational objectives and an opportunity to earn the funds necessary for continuing and completing their education.

These definitions of co-operative learning emphasise duality between an academic study area and a vocational training area. Additionally, agreements and co-operation concerning adjustments of education contents and education goals must be reached. The mentioned definitions clearly build on traditional vocational training structures. 


\section{Methods}

Theoretical and practical knowledge of co-operative education and training is scarcely available. In relation to energy transition, available information was collected and where some information gaps filled with new information. This research was carried out by means of a literature study and a database search on existing cooperative education formats. This was complemented by an analysis of seven actual case study reports regarding examples drawn from the BioEnergyTrain (BET) project commissioned under the European Union's Horizon 2020 programme.

\section{Results}

Dual studies usually answer to a specific skills profile defined by the business sector. They offer a particularly intense form of co-operation between business and HEIs; however, they are restricted to a relatively small number of curricula and institutions. In Germany, 7.2\% or 1432 of a total number of 19,822 study programmes are dual study programmes in the year [29].

Based on an extensive literature search, European cooperative dual study master's curricula were listed (Additional file 8: Table S1) and complemented with additional information and a performance evaluation for each study. In Europe, there are 73 master's study programmes based on dual education which amounts to $0.2 \%$ of a total of 34,283 masters' programmes in the year 2018. Thirty-eight studies or $52 \%$ of the master's studies based on dual education have a business or management background, 9 studies or $12 \%$ a technical one, 7 studies or $10 \%$ one connected with health service, and $26 \%$ have various other backgrounds ${ }^{1}$. Nineteen studies or $26 \%$ of the master's studies based on dual education are offered by traditionally diversified, deepened and specialised studies of universities, and 54 studies or $74 \%$ studies are offered by the more subject-specialised and business-oriented tertiary education institutions ranging from single private studies to high schools (Hochschule) and universities of applied sciences (Fachhochschule). A number of 26 public as well as private tertiary education institutions offer regular full-time, 23 part-time, 23 extra-occupational (parallel to employment) and 13 distance studies.

Since this study is not intended to offer an exhaustive list of dual studies (bachelor's studies based on dual education are not listed in Additional file 8: Table S1), this study provides a profile of typical dual studies currently available in Europe.

\footnotetext{
${ }^{1}$ These are computer science, law, sports, communication, systems sciences, architecture/design, religious science, archaeology, social studies, space technology, natural sciences and civic education.
}

Regarding the content of the dual studies in Europe dealing with the energy transition, huge deficiencies can be identified. Unquestionably, many dual study programmes exist already, but their focus usually is not on low-carbon or low-emission energy systems.

\section{Conventional co-operative learning formats on the course level}

Compared to the numbers regarding dual studies mentioned above, the selection of academic curricula is huge. 103,246 bachelor's degree studies and 72,207 master's degree studies are available worldwide [30]. A recent study by the European University Association (EUA) mapped the activities of European universities in the field of energy [31]. The EUA mapping gives an overview of education programmes compatible with the SET-Plan. Most of the selected master's programmes in priority areas of the SET-Plan are related to energy $(61.5 \%$ of 447 programmes).

Additional results are integrated in the whole document. Additional information about the collected results can be found in the case study reports available in Additional files 1, 2, 3, 4, 5, 6, 7 and 8 .

\section{Discussion}

\section{Roots of vocational training}

Vocational training has a far more co-operative tradition than tertiary education. In vocational training, there was no clear differentiation between theoretical and practical education. Apprentices were employed by a company and learned their trade from experienced workers in practical training. This is still practised in many European countries, e.g. Austria and Germany [32]. Today, this practical training is usually complemented with formal vocational training at special vocational schools.

In some professions requiring tertiary education, this traditional principle of dual education is still standard practice: medical doctors go through clinical rotation, and in many countries (e.g. Austria), lawyers are required to undergo an internship at a court before they are granted the right to practice their profession.

\section{Co-operation via placements and internships}

Concerning placements and internships which are less regulated, co-operation between academia and business is widely practised. The World Association for Cooperative \& Work-Integrated Education (WACE), a professional association dedicated to promoting cooperative \& work-integrated education, lists a total of 913 institutions they co-operated with in 52 countries worldwide [33].

This type of co-operation allows students to experience the work environment they will later work in. However, the quality of this experience differs widely, depending 
on the company that offers the internship, the position the student takes and the ability of the student to integrate into this environment. Usually, there is no educational structure at the site of the placement, and academic supervision accompanying these internships is rare.

A particular type of internships involves placements where students write reports or theses which are required academic output of their curricula. In these cases, co-operation between business and academia is closer: business usually defines the problems students have to address in these reports and theses. Assessment of the quality of these products usually remains with the academic teachers. The usability of the results evaluated by the business side may or may not become a factor in this academic assessment. This type of placements usually involves a certain amount of academic supervision and co-operation between the academic and business supervisors. This co-operation is not only beneficial to education but also enriches research as business and industrial problems are jointly researched by academia and business experts.

Although internships and placements are most valuable for student's experience and research co-operation, they lack comprehensive integration into the educational structure of academic curricula. Responsibility for as well as planning of educational aspects of internships and placements are not often shared between academia and business; usually, business takes responsibility for the student's work for the company while academia evaluates the quality of output according to their own standards only.

\section{Co-operative learning formats on the curricular level (dual studies)}

Based on the tradition of co-operative education in vocational training, there is a type of curriculum that combines theoretical education and practical training, usually performed in a company. Examples for these curricular-level co-operative learning formats are particularly described in North America and Europe. Dual study models in tertiary education emerged in Germany in the 1970s [34]. Awareness of these models had some ups and downs over time [35]. This led to a lack of a clear or consistent definition of dual tertiary education approaches [36]. However, terms like work-integrated learning (internships, service-learning, clinical placements), sandwich education (interspersed education in Great Britain and Canada) or learning factories [37] exemplify the development towards a similar goal but with heterogeneous designs.

In Europe, dual programmes in the course of tertiary education are seen as possible drivers for employability [38]. In the German-speaking part of Europe, this type of co-operative education and training approach is more clearly defined than in the English-speaking part where definitions are less clear which allows a more flexible application of specific education programmes and thus more adaptability in designing specific learning formats.

In Austria, the first dual tertiary education programme was developed at the University of Applied Sciences FH Joanneum. The goal was to find an alternative to traditional education programmes to solve ever more complex demands of the industrial sector [39]. 'The integration of work place experience has become an important element of diversification of higher education' [40]. The Austrian dual study programmes have since grown to curricula at six Universities of Applied Sciences (Fachhochschulen) with over 250 business partners [41].

Organisational set-up for co-operative education formats on the curricular level differs considerably. Haas differentiates them by three criteria [42]:

- Role of business

- Type of rotation

- Salary and legal issues

\section{Role of business}

Companies interact differently with universities that provide dual education curricula. An intensive level of interaction can usually be recognised within the German dual learning concepts in the course of which companies select and send students to university or comparable tertiary education institutions thus playing a major role in the process. In the USA and Canada, companies offer internships, usually for a period of about 4 months. Students select and apply for these internships independently. Therefore, the role of business is restricted to provide these internships. An intermediate level of interaction can be found in France and Austria where companies choose available first-year students who are then employed. Here, the students select the curriculum and are not sent to the institutions by the companies.

Business partners take over other responsibilities within dual education curricula as well, e.g.:

- Defining topics for courses and student projects

- Providing experts as lecturers

- Holding regular courses with business partners

- Defining course set-up with academic partners

- Providing infrastructure for courses and projects

Employability after graduation is a central goal from a socio-economic point of view, but this focus should not cover other important aspects of co-operative education such as ethics, responsibility, common wealth and independence [43]. 


\section{Type of rotation}

The schedule for rotation between theoretical education at HEIs and practical training in industrial or business environments differs between countries. In the USA, Canada, Germany (DHBW Duale Hochschule BadenWürttemberg, 1'Berufsakademie') and Austria (University of Applied Sciences - FH Joanneum), rotation usually takes place after 3 to 6 months. In Germany, with its 'Duale Studiengänge', a variety of rotation systems is to be found additionally. In Spain and Italy, students spend 2 to 3 days per week in the HEIs. The French 'Formation en Apprentissage' knows various rhythms-e.g. 2.5 days in a business environment and 2.5 days in a training centre (or alternatively 2 days of business and 3 days of training) [44].

\section{Salary and legal issues}

Ideally, dual curricular students receive payment similar to remuneration for an apprenticeship. Another possibility is to hire the student as a part-time employee for the duration of the programme and to postpone payment until the successful passing of the curriculum.

In a global context, the application of dual curricular formats is increasing. According to a recent study, the basic ideas behind the dual study system were exported from Germany to countries like Brazil, France, Qatar, Mexico and USA as it was described by Graf et al. [45].

\section{European efforts}

In order to push European universities towards intensifying activities concerning energy issues, the EUA developed a Roadmap for European Universities in Energy [46]. This roadmap includes 13 actions clustered around research and education, collaboration and effect. In this respect, collaboration includes actions to foster university networks and co-operation between universities and organisations in different sectors [46]. One of its particular goals is a stronger mobilisation of university and business co-operation. If co-operation between HEIs and business really shall contribute to establishing the highly qualified workforce necessary to reach the ambitious goal of a carbon-free energy system, it must not be restricted to dual study curricula. It must in fact become the new standard and part of each and every curriculum educating future engineers and energy experts in various fields. It must also become the basis for re-training and qualifying the current workforce to meet the challenges posed by the energy transition as described in the SET plan.

Available data on co-operative learning formats on the course level is poor and anecdotal. This is due to the facts that there are different approaches to co-operation in education and training between academic institutions and business and that it plays only a minor role in the particular national education systems. There is even less information on co-operative education programmes with a focus on energy, not to mention energy transition.

The most prevalent and traditional form of co-operation between HEIs and business on the course level is the participation of experts from business as guest lecturers in courses. In some cases, business experts may even be invited to conduct the courses entirely. Such cooperative learning formats expose students to business positions as well as to approaches and methods to solve problems used in business. This input by business experts certainly complements teaching by academic lecturers and may expand the student's horizon. It may also help students to throw their acquired knowledge into perspective by revealing how to use these skills in practice.

Even more intensive co-operative learning formats are seminars and design courses in which business define specific real-world problems and business experts help students to approach and solve these problems and give feedback on the applicability of the proposed solutions. In these seminars and courses, business experts are directly involved in course planning and implementation as well. Such learning formats provide students with practical insight into how to use their knowledge and skills. These seminars and design courses, moreover, provide students with access to supervision and feedback by academic as well as business instructors.

An ever-increasing number of HEIs offer lectures held by business experts as well as seminars and design courses with the participation of business instructors. Although they provide considerable advantages for both students and academic teachers and form an important link between business and academia, they do not provide exposure of students to business working environment, they contradict the general approach that tertiary education is exclusively planned, provided and evaluated by HEIs and that there is only indirect added value for business partners, mainly by generating a more qualified workforce that benefits not only business involved in the co-operation but also the competitors not involved.

\section{Innovative co-operative learning formats on the course level}

As the arguments above indicate, there is ample room for improvement, in particular for co-operative learning formats on the course level. This publication provides insight into some new approaches to such formats, based on case studies carried out in the course of the BioEnergy Train (BET) project commissioned by the European Union under the Horizon 2020 programme.

BET is put into effect by a consortium of HEIs, research centres, professional associations and industrial stakeholders. Its goal is to develop two new pilot 
master's curricula in fields specifically identified by the SRMET as critical to implementing the SET plan, namely the master's programmes Biorefinery Engineering at the Graz University of Technology in Austria and Bioresource Value Chain Management at the University of Twente in the Netherlands ${ }^{2}$. The consortium is headed by the European Sustainable Energy Innovation Alliance (eseia), a cross-sectoral association ${ }^{3}$. According to the guidelines of SRMET, the project is also tasked with the development and application of innovative co-operative learning formats.

\section{Student camps}

Arentsen, Kienberger and Bauer [Additional file 2] (from the viewpoint of academic teachers) and Ortner and Foxhall [Additional file 3] (from the viewpoint of business partners) describe a co-operative learning format known as 'student camp.' The general idea of this format is to assemble an interdisciplinary and international group of students and academic teachers at the site of a business partner. Academic teachers and business partners mutually select the problems to be discussed by the students, which are organised in interdisciplinary groups. These problems should be of strategic importance and highly relevant to the further development of the business partner.

The student camps have a duration of 1-2 weeks. In the beginning, the business partner should introduce the company and define the problems. He should also appoint a camp leader and company experts who should provide the student groups with advice and data.

Student camps are designed as student centred learning formats. The students are responsible for dealing with the specific problems, and academic teachers and company experts are prepared to be of assistance. Regular reports of the groups to the assembly of student camp participants allow exchanging of information. At the end of the student camp, the students should report their findings to company staff and academic teachers. Evaluation is done jointly by academic and business supervisors.

Feedback from students, academia and business is mainly positive. Students are highly motivated and can apply their knowledge to strategic real-world problems, thus gaining confidence in their skills. They experience interdisciplinary and international co-operation in a team, dealing with a specific and demanding task, as well as exposure to a business environment. Business partners derive profit from out-of-the-box thinking of

\footnotetext{
${ }^{2}$ See http://www.bioenergytrain.eu/the-project/ for more information [last visited December 2018]

${ }^{3}$ See http://www.eseia.eu/ for further information [last visited December 2018]
}

students and unconventional approaches to problems which are relevant to further company development. A particularly important aspect is that students also represent customers of the future, providing company managers with an insight into possible future preferences of their clients.

\section{Pilot plant research labs}

Arentsen, Kienberger and Bauer [Additional file 2] report on experiences with this format, in course of which a student group was allowed to operate pilot plant installations at the site of a business partner. The research plan for this operation was prepared in co-operation between academic teachers and business experts.

This format provides students with hands-on experience in operating industrial plants. They are confronted with the challenges and difficulties of real-world technological development.

The benefit for students is obvious. Academic teachers have the possibility to gain access to research infrastructure that is not available within HEIs. Business partners come to know possible future employees and are able to evaluate their skills in practice.

\section{Open summer schools}

The third co-operative learning format described by Arentsen et al. [Additional file 2] is known as 'open summer school'. These summer schools bring together interdisciplinary international student and academic teacher groups with business experts and address a specific topic. Although this format is closest to conventional co-operative course formats with teacher-centred instruction and supervised student exercises, it features some innovative aspects. Prominent among them is the fact that students are invited to bring their own tasks to the meeting. They are encouraged to take advantage of the interdisciplinary set-up of supervisors and of the access to business experts to get assistance in solving their specific problems.

Arentsen et al. [Additional file 2] say that the innovative value of these three co-operative formats results from:

- Linking industry to education in a new way

- Gaining an extended and deeper involvement with immediate industrial issues including problems and state-of-the-art knowledge and technology

- Fostering student-centred learning

- Performing a more interactive, reflective and groupcentred learning 
Collaborative non-traditional learning, distance learning and co-operative design courses

In non-traditional learning methods especially collaborative learning, approaches represent new ways for knowledge integration [47]. Compared to classical methods an integrative, group learning process helps to provide knowledge to students. Collaborative learning can also be supported by digital tools [48] or distance learning settings and open online resources [49].

Distance education is no recent phenomenon, but with the digital revolution, instant information and knowledge sharing increased significantly. Social media and onlinelearning, like Massive Open Online Courses (MOOCs) for an unlimited participation of people, Small Private Online Courses (SPOCs) for privates and Corporate Open Online Course (COOCs) for companies, contributed to sharing and spreading teaching content online, and in relation to cooperative forms of learning and creation, there is a differentiation between Generic Points of Cooperation (GPoC), Spontaneous Points of Creation (SPoC) and Intended Points of Creation (IPoC) [50]. Joan-Marc Joval [Additional file 5] reports on such a professional online learning platform. Professional digital education services and the passive role of learners are discussed. Co-operative design courses represent a chance for a co-creation of knowledge, and teacherlearner boundaries become less rigid when students are allowed to co-determine the design of a course. Moreover, online courses allow business partners not only to contribute to education on an equal footing with other actors. They also provide interesting tools for re-training and qualifying the existing workforce, a point particularly highlighted by SRMET as crucial for implementing the SET plan and a successful energy transition.

The article Structural Aspects of Co-operative Learning Formats states that experiences with co-operative learning formats are mainly positive. SRMET and AAEU attach great importance to the improvement of co-operation between business and HEIs. Krozer [Additional file 6] emphasises the importance of cooperative learning formats for the regional utilisation of bio-resources and the energy transition. Actually, the progress in developing and implementing these learning formats is rather slow. Structural hindrances and structural pre-conditions for wider implementation will have to be discussed.

Oswald [Additional file 4] points out a particular barrier for co-operation between academic education and business acquainted with vocational training: while academic education relies on workload-based evaluation, exemplified by the European Credit Transfer and Accumulation System (ECTS) system in Europe, vocational training uses skill-based evaluation in the
European Quality Assurance in Vocational Education and Training (EQAVET) system. He argues for a comprehensive and flexible education system combining academic and vocational training elements based on the needs of the market.

While such a comprehensive education system may still be a vision for the future, Sakulin et al. [Additional file 7] inform on advantages of regional clusters between HEIs, business and regional public and civil society actors. Experiences and potential benefits for participants from the collaboration of regional administrations with HEIs regarding co-operative learning formats are presented in a case study about a regional student camp in Austria and co-operative master's thesis supervision in Romania.

The latter report as well as the experiences gathered in the course of the BET project point out an important structural element for accelerated implementation of co-operative learning formats in existing and future curricula: the participation of mediating actors. The development of co-operative learning formats is not part of the core business of universities and companies. Moreover, these two actors follow very different rules and incentives. While scientific excellence and high educational standards secure public funding of universities, enrolment fees and research grants, business is driven by profit and shareholder value. Particular goals and planning horizons as well as management structures and decisionmaking differ considerably. All these differences are formidable barriers to co-operation between universities and business exceeding the level of temporary, clearly defined research projects. There is no indication for a change on this matter in the foreseeable future although this would be necessary to strengthen co-operation in education required by the energy transition.

If co-operative learning formats are to contribute to ensuring a workforce qualified to meet the future challenges, mediating actors are required. Experience from BET shows that mediating actors must have some general characteristics:

- They must integrate stakeholders coming from universities, business and, perhaps, from the public sector and the civil society;

- They must be dedicated to a particular future challenge; in the present case, this would be the energy transition;

- They must have a track record of co-ordinating cooperation between the stakeholders.

The clusters discussed in Sakulin et al. [Additional file 7] as well as by eseia which co-ordinates the BET project have 
these characteristics and, therefore, were able to co-ordinate and implement co-operative learning formats in their own specific environment.

The examples of successful and innovative learning formats established within the BET project however show another aspect: these formats are the result of an interdisciplinary and international innovation process that answered to the specific challenges for education posed by the energy transition as stated in SET Plan Roadmap on Education and Training (SRMET). Intersectoral actors like eseia who operate internationally and are actively involved in the changing process necessary for the energy transition are able to succeed in getting things done in this respect.

\section{Conclusions}

The energy transition requires a future workforce dealing with low emission energy systems that is not only considerably larger than the current one but also capable of handling new technologies and complex systems and of pushing ahead innovation. The European Union's Strategic Energy Technology (SET) Plan Roadmap on Education and Training (SRMET) has recognised that considerable changes in education and training will be necessary. SRMET and also the Action Agenda of European universities AAEU calls for close co-operation between educational institutions and business to meet the formidable quantitative and qualitative challenges to establish the large and highly qualified workforce for the energy transition. Co-operative learning formats are vital for the energy transition as well as for improved academic education.

There is already a certain tradition of co-operation between universities and business in the form of internships and placements of students in companies during their education. While this is an important way to expose students to their future work environment, it usually lacks educational structure and joint responsibility for the learning outcome.

On the curricular level, dual studies offer a more structured form of co-operative education. In these curricula, theoretical instructions at HEIs and practical work and on-the-job-training take turns. They usually answer to immediate demand by business for qualified employees in a particular and narrow field. Dual studies however represent only a tiny minority of studies offered by HEIs.

In order to influence the shape of the majority of existing curricula and to design innovative new curricula aimed explicitly at pushing ahead the energy transition, broad co-operation between academia and business on the course level is required. Guest lectures by business experts within regular curricula as well as seminars and design courses with the participation of industry are existing types of co-operation that can form the basis for closer linkage in future. In order to achieve both, deeper collaboration and higher quality of education, innovative types of co-operative learning formats on the course level have to be developed. Examples of such formats show that they are advantageous for business, students and academic teachers.

An analysis of the experiences made in the course of the BET project points out the importance of mediating actors who facilitate the co-operation between business and universities. Mediating actors are necessary as there are fundamental differences in goals, intentions and management structures of academia and business. They must integrate members from both sides and already have a positive track record of co-operation concerning specific projects connected with the energy transition in order to succeed in meeting the ambitious goals for cooperative learning formats described in SRMET and AAEU alike. Given the urgency of implementing a lowcarbon energy system in the face of climate change, efforts to bring business and HEIs together for the purpose of educating the future and re-training the existing workforce have to increase dramatically.

\section{Additional files}

Additional file 1: Case study 1. Co-operative Learning Formats - an important Link in the Chain to implement the SET Plan. (DOCX 45 kb)

Additional file 2: Case study 2. Experiences of BET Lecturers with Cooperative Learning Formats. (DOCX 37 kb)

Additional file 3: Case study 3. Requirements and potential Benefits for the Industry from Cooperative Learning Formats with HEls. (DOCX 39 kb)

Additional file 4: Case study 4. Lifelong Learning with the "Education and Training Paths by WKO" (Austrian Economic Chambers). (DOCX 181 $\mathrm{kb})$

Additional file 5: Case study 5. Professional Online Learning at InnoEnergy - A lean Approach to Creating activating Online \& Blended Learning. (DOCX $307 \mathrm{~kb}$ )

Additional file 6: Case study 6. How Learning Materials based on regional Challenges can help to build Communities for the Energy Transition. (DOCX $39 \mathrm{~kb}$ )

Additional file 7: Case study 7. Benefits and Requirements for Regional Administration from Co-operative Learning Formats with Higher Educational Institutes (HEls). (DOCX $37 \mathrm{~kb}$ )

Additional file 8: Table S1. Existing co-operative dual studies with master's programmes in Europe. (DOCX $41 \mathrm{~kb}$ )

\section{Abbreviations}

AAEU: Action Agenda for European Universities; BET: BioEnergyTrain (project); COOC: Corporate Open Online Course; DHBW: Duale Hochschule Baden -Württemberg (engl. Dual College/University); ECTS: European Credit Transfer and Accumulation System; EQAVET: European Quality Assurance in

Vocational Education and Training; eseia: European Sustainable Energy Innovation Alliance; ET: Education and training; EUA: European University Association; FH: Fachhochschule (engl. University of Applied Sciences); GPoC: Generic Points of Cooperation; HEl: Higher education institutions; IPOC: Intended Points of Creation; MOOCs: Massive open online courses; SET: Strategic Energy Technology; SPOC: Small Private Online Courses; SPoC: Spontaneous Points of Creation; SRMET: SET Plan Roadmap on 
Education and Training; WACE: World Association for Cooperative \& Work -Integrated Education

\section{Acknowledgements}

The authors would like to thank the team of the BioEnergy Train (BET) project for sharing experiences with developing co-operative education formats

\section{Authors' contributions}

MN reviewed and contributed to the meta-study and case studies. SM did the literature review and prepared the manuscript for the meta-study. All authors read and approved the final manuscript.

\section{Authors' information}

MN was a professor at the Institute of Process and Particle Engineering at the Graz University of Technology. Before he retired, his field of research was sustainable systems and he led the working group Process Synthesis, Process Evaluation, and Regional Development. He headed the Bioenergy Working Group within the SET-Plan Education Task Force of the European Commission, chaired the Bioresources Working Group of the European Sustainable Energy Innovation Alliance (eseia) and held other positions in the field of sustainability. $\mathrm{He}$ is the inventor of the ecological footprint (method Sustainable Process Index) and has published a number of papers on sustainability indicators and sustainable regional development.

SM works at the working group sustainable construction at the Institute of Technology and Testing of Construction Materials and is the co-founder of STRATECO OG, a company working in the field of ecological footprinting and optimal technology systems in regional development. He graduated in environmental systems sciences at the University of Graz. He supplemented his experiences in the field of process evaluation with the support of the Graz University of Technology and holds a PhD.

\section{Funding}

This publication was funded by the BET project itself in order to gain

knowledge of the newly developed education and training plans.

\section{Ethics approval and consent to participate}

Not applicable.

\section{Consent for publication}

Not applicable.

\section{Competing interests}

The authors declare that they have no competing interests.

\section{Author details}

'eseia/Graz University of Technology, Graz, Austria. ${ }^{2}$ EUA, Brussels, Belgium. ${ }^{3}$ University of Twente, Enschede, Netherlands. ${ }^{4}$ Green Tech Cluster, Graz, Austria. ${ }^{5}$ BRP-Rotax, Gunskirchen, Austria. ${ }^{6}$ OSIT, Sankt Andrä, Austria. ${ }^{7} \mathrm{KIC}$ InnoEnergy, Eindhoven, Netherlands. ${ }^{8}$ Energy Agency of Styria, Graz, Austria. ${ }^{9}$ Biomass Cluster Bio-C, Sfântu Gheorghe, Romania. ${ }^{10}$ University of Zagreb, Zagreb, Croatia.

Received: 15 January 2019 Accepted: 8 July 2019

Published online: 25 July 2019

\section{References}

1. Wessels ML, Jacobsz JM (2011) Views of industry and higher education on cooperative education in the Gauteng Province of South Africa. First CGUWACE International Symposium and WACE's Seventh International Symposium on Work Integrated Learning, Madrid, SPAIN, pp 1-25 https:/www.waceinc. org/papers/madrid/Marius\%20Wessels.pdf

2. Kessels J, Kwakman K (2007) Interface: establishing knowledge networks between higher vocational education and businesses. High Educ 54(5):689703. https://doi.org/10.1007/s10734-006-9018-4

3. Culkin N, Mallick S (2011) Producing work-ready graduates: the role of the entrepreneurial university. Int J Market Res 53(3):347-368. https://doi.org/1 0.2501/IJMR-53-3-347-368

4. Rufai AU, Bin Bakar AR, Mat Rashid A (2015) Business, industry and higher education collaboration: a panacea in developing professional work-ready graduates. Mediterr. J. Soc. Sci. 6(6):512-518 ISSN 2039-2117. 10.5901/mjss.2015.v6n6p512

5. Haynes CJ (2009) Holistic human development. J Adult Dev 16(1):53-60. https://doi.org/10.1007/s10804-009-9052-4

6. Rösch C, Bräutigam KR, Kopfmüller J, Stelzer V, Fricke A (2018) Sustainability assessment of the German energy transition. Energy Sustain Soc 8(1):12. https://doi.org/10.1186/s13705-018-0153-4

7. Nathan S, Taylor N (2003) Linking cooperative education and education for sustainability: a new direction for cooperative education? Asia-Pac j coop educ 4:1), 1-1), 8 https://www.ijwil.org/files/APJCE_04_1_1_8.pdf

8. UNESCO (2017) Education for sustainable development goals - learning objectives. ISBN 978-92-3-100209-0. https://unesdoc.unesco.org/in/ documentViewer.xhtml?v = 2.1.196\&id = p.:.usmarcdef_0000247444\&file=/in/ rest/annotationSVC/DownloadWatermarkedAttachment/attach_import_826 03519-4d73-431c-9324-8e0dcc1b6b1e\%3F \%3D247444eng.pdf\&locale = en\&multi = true\&ark=/ark:/48223/pf0000247444/PDF/247444eng.pdf\#815_1 8_Learning\%200bjectives_int_En.indd\%3A.121503\%3A371.

9. European Commission (2018) Europe 2020 strategy. Available at: https:/ec.europa. eu/info/business-economy-euro/economic-and-fiscal-policy-coordination/eu -economic-governance-monitoring-prevention-correction/european-semester/ framework/europe-2020-strategy_en (Accessed 19 Jan 2019)

10. European Commission (2017) SET-Plan. Available at: https://ec.europa.eu/ energy/en/topics/technology-and-innovation/strategic-energy-technologyplan (Accessed 19 Jun 2019)

11. Joint Research Centre (JRC) (2014) Strategic Energy Technology (SET) Plan: Towards an Integrated Road Map: Research \& Innovation Challenges and Needs of the European Energy System. doi:https://doi.org/10.2790/16458.

12. European Commission (2016) Europe 2020 targets: statistics and indicators at EU level. Available at: https://ec.europa.eu/. Accessed 19 Jan 2018.

13. Journal of the European Union (2009) Council - Notices from European Union Institutions and Bodies. Council conclusions of 12 May 2009 on a strategic framework for European cooperation in education and training (ET 2020). C 119/02:1-9. Available at: https://www.cedefop.europa.eu/files/ education benchmarks 2020.pdf. Accessed 19 June 2019.

14. European Union (2017) The Strategic Energy Technology (SET) Plan - At the heart of Energy Research and Innovation in Europe - 2007-2017 Set Plan 10th Anniversary. 1-88. doi:https://doi.org/10.2777/47633.

15. Joint Research Centre (JRC) (2014) Strategic Energy Technology (SET) Plan Towards an Integrated Roadmap: Research \& Innovation Challenges and Needs of the EU Energy System. JRC93056:1-54. Available at: https://setis.ec. europa.eu/system/files/Towards\%20an\%20Integrated\%20Roadmap_0.pdf (Accessed 19 Jun 2019)

16. European Commission (2018) Education \& Training Roadmap. Study on Energy Education and Training in Europe:1-616. https://doi.org/10.2790/3042

17. European Commission. SETIS information for decision-making: actions towards implementing an integrated road map. Available at: https:// setis.ec.europa.eu/set-plan-process/integrated-roadmap-and-action-plan (Accessed Jun 2019)

18. European University Association (EUA) (2017a) Energy transition and the future of energy research, innovation and education: an action agenda for European Universities. 1-60. Available at: https://energy.eua.eu/downloads/ publications/energy-transition.pdf. Accessed June 2019.

19. United Nations (2018) Sustainable Development Goals. SDG 4 Quality Education. Available at: https://www.un.org/sustainabledevelopment/ education/ (Accessed Jun 2019)

20. Nowotny J, Dodson J, Fiechter S, Gür TM, Kennedy B, Macyk W, Bak T, Sigmund W, Yamawaki M, Rahman KA (2018) Towards global sustainability. Education on environmentally clean energy technologies. Renew Sust Energ Rev 81:2541-2551. https://doi.org/10.1016/j.rser.2017.06.060

21. Fleming J (2015) Exploring stakeholders' perspectives of the influences on student learning in cooperative education. Coop Educ 16(2):109-119

22. Scager K, Boonstra J, Peeters T, Vulperhorst J, Wiegant F (2016) Collaborative learning in higher education. Evoking Positive Interdependence. CBE Life Sci Educ 15(4):/ar69:1-/ar69:9. https://doi.org/10.1187/cbe.16-07-0219

23. Warhuus JP, Tanggaard L, Robinson S, Ernø SM (2017) From I to We Collaboration in entrepreneurship education and learning. Educ + Train 59(3):234-249. https://doi.org/10.1108/ET-08-2015-0077

24. Healy A, Perkmann M, Goddard J, Louise K (2014) Measuring the impact of university business cooperation. Final Report, EAC/23/2012. Available at: https://www.eurashe.eu/library/mission-phe/NC0214337ENN_002.pdf. Accessed 26 Oct 2018 
25. Ricks F (1996) Principles for structuring cooperative education programs Coop Educ 31(2-3):8-22 ISSN: ISSN-0022-0132

26. CEWIL (2018) Co-operative education and work-integrated learning Canada. Available at: https://www.cewilcanada.ca/ (Accessed 23 February 2018)

27. WACE (2018a) Advancing cooperative \& work-integrated education. Available at: www.waceinc.org (Accessed 26 February 2018)

28. US law (2008) Cooperative education. Pub. L. 89-329, title VIII, § 831, as added Pub. L. 110-315, title VIII, § 801, Aug. 14, 2008, 122 Stat. 3415.

29. Zeit Campus (2018) Studiengänge. Available at: https://studiengaenge.zeit. de/studienangebote (Accessed Jun 2019)

30. Study Portals (2018) Bachelors. Available at: https://www.bachelorsportal.com (Accessed 31 Aug 2018)

31. European University Association (EUA) (2017b) Energy research and education at European universities - The UNI-SET Universities Survey Report. Available at: https://eua.eu/downloads/publications/the\%20energy\%2 Oresearch\%20and\%20education\%20landscape\%20at\%20europes\%2 Ouniversities.pdf (Accessed Jun 2019)

32. Federal Ministry of Education and Research (BMBF). The German vocational training system. https://www.bmbf.de/en/the-german-vocational-trainingsystem-2129.html (Accessed 19 Jun 2019)

33. WACE (2018b) Wace global institutions. Available at: http://www.waceinc. org/global_institutions.html (Accessed 31 August 2018)

34. Nickel S, Püttmann V (2015) Qualitätsentwicklung im dualen Studium - Ein Handbuch für die Praxis. Stifterverband für die Deutsche Wissenschaft. 1143. ISBN: 978-3-922275-64-0 . https://www.bibb.de/dokumente/pdf/ Stifterverband_Handbuch_Qualitaetstentwicklung_im_dualen_Studium.pdf (Accessed 19 Jun 2019)

35. Grubb WN, Villeneuve JC (1995) Co-operative education in Cincinnati: implications for school-to-work programs in the U.S. Tech Assist Rep https:// files.eric.ed.gov/fulltext/ED388860.pdf (Accessed 19 Jun 2019

36. Ricks F, Cutt J, Branton G, Loken M, van Gyn GH (1993) Reflections on the cooperative education literature. Coop Educ 29(1)EJ 475 316):6-23. ISSN: ISSN-0022-0132.

37. Abele E, Metternich J, Tisch M, Chryssolouris G, Sihn W, ElMaraghy H, Hummel V, Ranz F (2015) Learn Factor Res Educ Train Procedia CIRP 32:1-6. doi: https://doi.org/10.1016/.jprocir.2015.02.187

38. EuroDuaLE (2015) Intellectual Output 2. Analysis of existing dual learning programmes as drivers for employability - state of the art of existing dual learning programmes. Available at: http://www.euroduale.eu/images/ documents/O2 english.pdf (Accessed Jun 2019)

39. FH Joanneum (2018) Cooperative education in engineering. Available at: https://www.fh-joanneum.at/en/schwerpunkt/cooperative-education-inengineering/ (Accessed Jun 2019)

40. Haas J (2016b) Different modes of delivery - dual education programmes Presentation 1-43. Available at: https://www.eurashe.eu/library/quality-he/ EQUIP_160606-07_Lisbon_pres_HAAS.pdf (Accessed Jun 2019)

41. Fachhochschule Vorarlberg (2018), Dual Studieren Österreich. Available at: http://www.dualstudieren.at/ (Accessed Jun 2019)

42. Haas J (2016a) Challenges in European higher education and the role of dual study programmes. PLA on Dual Educ Budapest. 1-42. Available at: http://www.tpf.hu/docs/palyazatok/haas_pla_budapest_29092016.pdf (Accessed Jun 2019)

43. Stokes PJ (2015) Higher education and employability: new models for integrating study and work. Harvard Education Press, Cambridge, MA, pp 1189 ISBN: 978-1-61250-826-9

44. Alternance Emploi (2018) Formations et Emplois en Alternance. Available at: http://www.alternancemploi.com/ (Accessed Jun 2019)

45. Graf L, Powell JJW, Fortwengel J, Bernhard N (2014) Duale Studiengänge im globalen Kontext: Internationalisierung in Deutschland und Transfer nach Brasilien, Frankreich, Katar, Mexiko und in die USA - Dual study programmes in global context: Internationalisation in Germany and transfer to Brazil, France, Qatar, Mexico and the US, Dok \& Mat / Deutscher Akademischer Austauschdienst, DAAD, 77:1-129, ISBN 978-3-87192-913-7

46. European University Association (EUA) (2016) Roadmap for European Universities in Energy. Universities in the SET-plan. Available at: https://eua. eu/downloads/publications/roadmap\%20for\%20european\%20universities\%2 Oin\%20energy\%201\%20december\%202016.pdf. Accessed 24 Jan 2018.

47. Lukman, Rebeka \& Krajnc, Majda. (2012). Exploring non-traditional learning methods in virtual and real-world environments. Educ Tec Society 15(1):237247. https://pdfs.semanticscholar.org/5525/bcba57e1ef2c067364c64 ebfdbe90087ca3f.pdf (Accessed Jun 2019)
48. Kirschner PA (2001) Using integrated electronic environments for collaborative teaching/learning. Learn Instruct:10(1):1-10(1):9. https://doi. org/10.1016/50959-4752(00)00021-9

49. Okada A, Scott PJ, Connolly T (2012) Collaborative learning 2.0 - open educational resources. IGI Global:1-378. https://doi.org/10.4018/ 978-1-4666-0300-4

50. Wessner M, Pfister HR (2007) Points of cooperation - integrating cooperative learning into web-based courses. Comp Support Collaborat Lear 9:21-46. https://doi.org/10.1007/978-0-387-71136-2_3

\section{Publisher's Note}

Springer Nature remains neutral with regard to jurisdictional claims in published maps and institutional affiliations.
Ready to submit your research? Choose BMC and benefit from:

- fast, convenient online submission

- thorough peer review by experienced researchers in your field

- rapid publication on acceptance

- support for research data, including large and complex data types

- gold Open Access which fosters wider collaboration and increased citations

- maximum visibility for your research: over $100 \mathrm{M}$ website views per year

At BMC, research is always in progress.

Learn more biomedcentral.com/submissions 